\title{
Effects of leaf herbivory on the bromeliad Aechmea blanchetiana: a study of selective feeding by the scraper Acentroptera pulchella
}

\author{
Noa Magalhães ${ }^{1}$, Lucas Bevilaqua Ferreira ${ }^{1}$, Gilda Leitão ${ }^{2}$ and André Mantovani ${ }^{1,3}$
}

Recebido em 15/03/2011. Aceito em 23/07/2012

\begin{abstract}
RESUMO
(Efeito da herbivoria foliar na bromélia Aechmea blanchetiana: estudo sobre o padrão seletivo de forrageamento do inseto raspador Acentroptera pulchella). O raspador Acentroptera pulchella (Chrysomelidae, Hispinae) foi observado se alimentando de folhas de Aechmea blanchetiana (Bromeliaceae), mas não de forma indiscriminada. Este inseto aparentemente concentra seu ataque na metade superior das folhas intermediárias do tanque da bromélia. A fim de caracterizar a potencial influência de estratégias defensivas contra herbivoria no padrão alimentar intra-específico de A. pulchella, sobre folhas da bromélia A. blanchetiana, nós: i) quantificamos a aparente preferência intra-específica deste padrão alimentar, ii) comparamos folhas e partes distintas em relação à estratégias morfo-fisiológicas, mecânicas, nutricionais e químicas contra herbivoria e iii) avaliamos se algumas ou todas estas estratégias defensivas ajudariam a explicar o padrão alimentar observado. O raspador A. pulchella atacada preferencialmente a metade superior de folhas intermediárias e adultas de A. blanchetiana, mas não a metade inferior das mesmas folhas, as quais são mais resistentes à perfuração, mais espessas e apresentam menor teor de nitrogênio do que a parte superior. Ao mesmo tempo, porém, folhas jovens e tenras não foram atacadas. As metades atacadas também apresentaram maior teor de fenóis totais em comparação as não atacadas, indicando que os fenóis não atuam defensivamente neste caso. Outras estratégias morfo-fisiológicas e químicas contra herbivoria não variaram entre as partes ou folhas aqui avaliadas. $\mathrm{O}$ herbívoro estudado se alimenta preferencialmente de partes das folhas com maior teor de nitrogênio, evitando ao mesmo tempo outras com maior resistência à perfuração. Concluímos que o raspador A. pulchella apresenta claro padrão seletivo de forrageamento, onde o mesmo é direcionado mais por benefícios nutricionais do que estritamente por estratégias mecânicas ou químicas contra herbivoria.
\end{abstract}

Palavras-chave: Bromeliaceae, herbivoria foliar, raspador

\begin{abstract}
(Effects of leaf herbivory on the bromeliad Aechmea blanchetiana: a study of selective feeding by the scraper Acentroptera pulchella). The scraper Acentroptera pulchella (Chrysomelidae, Hispinae) feeds on the leaves of Aechmea blanchetiana (Bromeliaceae), but not indiscriminately. This insect apparently concentrates its attack on the apical region of the intermediate leaves from the bromeliad tank. To characterise the potential influence of leaf defensive strategies on the intraspecific feeding pattern of A. pulchella on the leaves of the bromeliad A. blanchetiana, we quantified the apparent intraspecific preference of this feeding pattern; compared distinct leaves and portions in relation to morpho-physiological, mechanical, nutritional and chemical anti-herbivore strategies; and investigated whether some or all these defensive strategies help explain the observed feeding pattern. A. pulchella preferentially attacked the mid-upper portions of mature and adult leaves of A. blanchetiana, but not the mid-lower portions of the same leaves, which are more resistant to punch, are thicker and present less nitrogen content than the upper portions. However, soft young leaves were not attacked. Attacked portions also presented higher total phenol content than did non-attacked portions, indicating that phenols do not act defensively. Other morpho-physiological and chemical anti-herbivore strategies evaluated did not differ between portions and leaves. This herbivore feeds preferentially on leaf portions that have higher nitrogen levels, avoiding others that present increased punch resistance. The scraper $A$. pulchella exhibits a clearly selective feeding pattern that is driven by nutritional benefits rather than strictly mechanical or chemical anti-herbivore strategies.
\end{abstract}

Key words: Bromeliaceae, leaf herbivory, scraper

\footnotetext{
${ }^{1}$ Instituto de Pesquisas Jardim Botânico do Rio de Janeiro, Rio de Janeiro, RJ, Brazil

${ }^{2}$ Universidade Federal do Rio de Janeiro, Centro de Ciências da Saúde, Núcleo de Pesquisas de Produtos Naturais, Rio de Janeiro, RJ, Brazil

${ }^{3}$ Author for correspondence: andre@jbrj.gov.br
} 


\section{Introduction}

In their revision of insects and allies associated with bromeliads, Frank \& Lounibos (2009) report herbivory attacks by miners and grazers. Although some information is available about miners and grazers (Benzing 2000), very little is known about scrapers of the Bromeliaceae. Scrapers commonly attack on the adaxial or abaxial surface, leaving some mesophyll layers and the opposite epidermis intact. None of the previous studies of bromeliad scrapers (Lowman et al. 1996; DeVries 1997; Schmidt \& Zotz 2000) have evaluated intrinsic leaf properties that might influence their feeding pattern.

Mantovani et al. (2005) found that the scraper Acentroptera pulchella Guérin-Méneville (Chrysomelidae, Hispinae) feeds on the leaves of Aechmea blanchetiana (Baker) LB Sm. (Bromeliaceae). This herbivore scrapes the leaf from the outside, mainly through the adaxial epidermis, consuming the mesophyll tissues (hypodermis, chlorenchyma, vascular tissue and sclerenchyma), leaving intact only four to five layers of cells. Cicatrisation of the open wounds was complete after three days of attack. The remaining mesophyll cells became dry, exhibiting a cork-like appearance, and the wound was then entirely surrounded by a deep red stripe caused by the deposition of tannins at the cellular level (Mantovani et al. 2005).

However, the scraper $A$. pulchella did not attack all leaves of $A$. blanchetiana. Cicatrised wounds on several attacked bromeliads show that scraper activity is apparently concentrated on intermediate and adult leaves surrounding the bromeliad tanks and then on the mid-upper portion of these leaves. This feeding preference motivated us to conduct an intraspecific comparison between leaf ages and portions to detect anti-herbivore properties that can lead to this choice. We hypothesise that the differential occurrence of anti-herbivore strategies at leaf level could induce such spatial feeding preference of $A$. pulchella for the mid-upper portion of the bromeliad leaves.

Plants present several morpho-physiological, mechanical, chemical and nutritional anti-herbivore strategies at leaf level, all of which minimise the level of herbivory (Aide 1993; Forkner et al. 2004). Examples of morpho-physiological strategies include thick epidermis, trichomes, lignified fibres and low succulence (Scriber 1977; Bernays \& Chapman 1994). Mechanical limitation is caused by structural properties that increase strength-to-punch, which is the maximum force (or an equivalent measure) per unit punch area to penetrate a leaf (Lowman \& Box 1983; Read \& Sanson 2003). Finally, chemical deterrents, such as tannins, are metabolites that make a leaf less attractive to a herbivore (Harbone 1982; Sagers \& Coley 1995), as do tissues with a low nutrient content (Feeny 1970; Wheeler \& Center 1996; 2001). Intraspecific variations of these anti-herbivore strategies can occur at distinct ontogenetic stages of the leaf. Qualitative and quantitative variations have already been reported for young and adult leaves of the same individual (Lowman \& Box 1983; Nichols-Orians \& Schultz 1990; Aide 1993), or even different portions of the same leaf (Scheirs et al. 1997). However, to the best of our knowledge, there are no intraspecific studies addressing the herbivory for Bromeliaceae (Dominy et al. 2008; Frank \& Lounibos 2009).

To demonstrate that the spatial intraspecific feeding pattern of A. pulchella on the leaves of the bromeliad A. blanchetiana is influenced by leaf anti-herbivore strategies, this paper had multiple aims: to quantify the apparent intraspecific preference of this feeding pattern; to compare distinct leaves and portions in relation to distinct anti-herbivore traits; and to determine whether some or all these defensive strategies help explain the observed spatial feeding pattern of $A$. pulchella on the leaves of A. blanchetiana.

\section{Materials and methods}

\section{Study site, plant species, insect species and the collection of plant material}

The study was developed in the arboretum of the Rio de Janeiro Botanical Garden Research Institute (2258'03.96”'S; $\left.043^{\circ} 13^{\prime} 26.80^{\prime \prime} \mathrm{W}\right)$. The macro-climate at the study site is Köppen climate classification Am (Mantovani and Pereira 2005), with mean air temperatures of $29^{\circ} \mathrm{C}$ and $22^{\circ} \mathrm{C}$ during summer and winter, respectively, and mean annual precipitation (rainfall) of $\approx 1075 \mathrm{~mm}$. Approximately 200 distinct ramets of $A$. blanchetiana from the bromeliad collection were monitored to detect the presence of $A$. pulchella during three winter months (dry season), from June to August 2004, and two summer months (rainy season), December 2004 and January 2005. As A. pulchella was found to be more active during summer, this season was chosen as our study period.

Wounds generated by $A$. pulchella in bromeliad leaves are clearly characteristic and distinguishable (Mantovani et al. 2005). Male and female individuals of $A$. pulchella attack bromeliad leaves generating long, narrow wounds $(20-\geq 100$ $\mathrm{mm}$ in length and $2-5 \mathrm{~mm}$ in width), resembling stripes, which are mainly concentrated on the distal portion of the leaf (Figure 1).

In this paper, we have made the assumption that the intraspecific feeding pattern of $A$. pulchella on the leaves of $A$. blanchetiana is potentially determined by morpho-physiological, mechanical, nutritional and chemical anti-herbivore strategies. To make this assessment, we first detected intact ramets of $A$. blanchetiana where the herbivore had been feeding for one to two days. Extreme care was taken not to inhibit the feeding insect, as any interference could have potentially decreased the consumed leaf area (Mantovani et al. 2005). As the insects left a given ramet, the attacked leaves were collected for analysis. Rapid collection of the attacked leaves was important for chemical analysis, as increased production of a secondary compound after insect attack has been reported (Harbone 1982). 

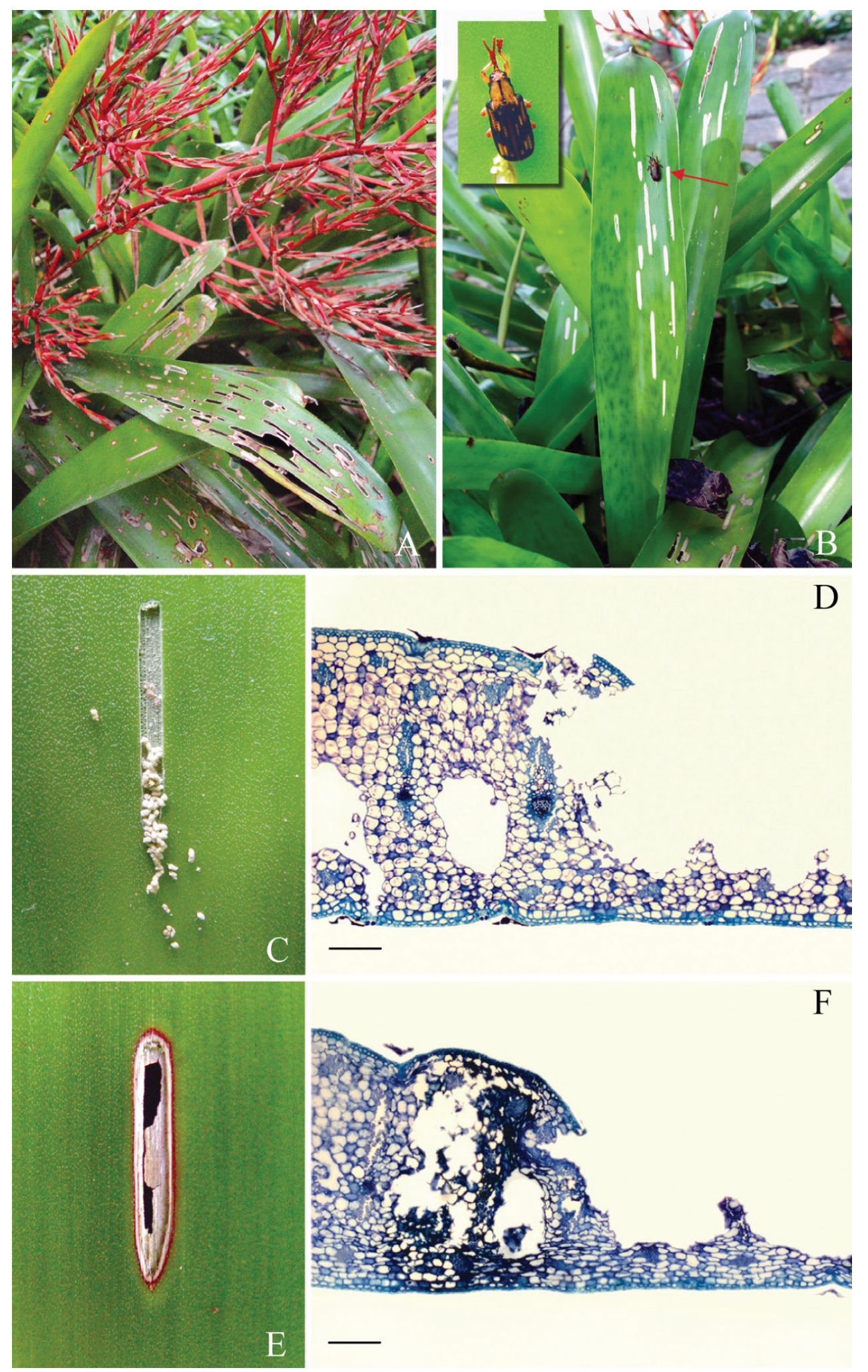

Figure 1. Acentroptera pulchella Guérin-Méneville causes selective damage to leaves of Aechmea blanchetiana (Baker) LB Sm. (A) Note the long, narrow wounds concentrated on the mid-up portions of leaves; (B) A. pulchella (arrow and in detail) in action, chewing a mid-up portion of a mature leaf of A. blanchetiana; (C) Recently attacked area of A. blanchetiana leaf. Note the insect faeces eliminated during chewing. Remains of vascular bundles are apparent inside the wounded area; (D) Leaf transversal section of a recently attacked area. Note the remaining mesophyll, comprising an almost intact vascular bundle, 5-6 chlorenchyma layers and abaxial hypodermis. Scale bar $=135 \mu \mathrm{m} ;($ E) Cicatrised area surrounded by a phenolic region, characterised by a thin, deep-coloured ring (arrow); (F) Leaf transversal section of cicatrised area: Note the deep-coloured cells on the left, corresponding to the phenolic ring. Scale bar $=135 \mu \mathrm{m}$. 
Five ramets of $A$. blanchetiana with signs of attack by $A$. pulchella had all their leaves marked and numbered. From each ramet, three leaves were collected, each one from a distinct tank position: young leaf, between first and third leaf in the inner portion of the tank; mature leaf, between the fourth and ninth leaf of the tank; old leaf, between the tenth leaf and the outermost leaf of the tank. The leaves were collected, stored in humidified plastic bags and brought to the laboratory. Each leaf was then divided into two equal portions: basal, (mid-lower portion) and distal (mid-upper portion). The analysis of each ramet is based on one young, one mature and one old leaf, each divided into basal and distal portions. Therefore, from a total of five ramets, we evaluated 15 leaves (young, mature and old, five each) and 30 mid-upper and mid-lower leaf portions. For each basal and distal portion of leaves of $A$. blanchetiana, the percentage of leaf area attacked was first determined. Anti-herbivore traits were then evaluated for the same leaf portions.

\section{Quantification of consumed areas}

The percentage of the leaf area attacked by A. pulchella was determined for each mid-lower and mid-upper portion of young, mature and adult leaves from each ramet of A. blanchetiana. Leaf portions were digitally photographed using a millimetre scale, and the amount of attacked area, expressed as a percentage of the total leaf area, was determined using the Scion Image software (Scion Corporation, Frederick, MD, USA).

\section{Mechanical and morpho-physiological anti-herbivory leaf traits}

Anti-herbivore defence accomplished via mechanical properties of the leaf was evaluated by the maximum force-to-punch value obtained by using a penetrometer, as proposed by Fenny (1970) and as already used in other studies (Lowman \& Box 1983; King 1988; Burgess et al. 1998). To accomplish this, the device used here is described below and was constructed with improvements suggested by Aranwela et al. (1999). Briefly, two acrylic plates (185 mm in width $x$ $70 \mathrm{~mm}$ in length $\times 25 \mathrm{~mm}$ in height) hold the leaf tightly, while a flat-ended, sharp-edged cylindrical brass punch (diameter of $1.0 \mathrm{~mm}$ ) with a $1.5 \mathrm{~mm}$ clearance is forced against it. The rod diameter varies in different reported studies (Lowman \& Box 1983; King 1988). In the present study, a 1.0-mm diameter rod was used to approximate the width of the insect mandible. Force is generated by carefully and continuously filling a beaker positioned above the rod, avoiding any impact caused by large displacements of water. The maximum force necessary to punch the rod through the leaf divided by the area over which the force was applied (the rod area) is herein termed "strength-to-punch" (Read \& Sanson 2003). Ten punch-strength measurements at the midpoint of each leaf portion were determined, and a partial mean value was obtained. A final mean was calculated using the five partial means obtained above for each basal and distal portion of young, mature and adult leaves.
Morpho-physiological strategies were evaluated by the following anatomical characteristics: epidermis+mechanical hypodermis thickness at the adaxial surface; whole leaf thickness; percentage of transversal area of leaf occupied by fascicular and extra fascicular fibres (Tomlinson 1969); and leaf succulence (Mantovani 1999). In order to quantify the anatomical characteristics from the same leaf portions where resistance to punch was determined, five $0.3 \times 0.5 \mathrm{~cm}$ fragments were obtained from each leaf portion. The material was fixed in glutaraldehyde $2.5 \%$ and paraformaldehyde $10 \%$ in phosphate buffer $0.2 \mathrm{M}$, dehydrated in a graded alcohol series $\left(10-100^{\circ} \mathrm{GL}\right)$, embedded in methacrylate resin (Historesin; Leica Microsystems, Nussloch, Germany) and sectioned with a rotating microtome. One transversal section per fragment was obtained. The sectioned material was mounted on microscope slides and observed under bright field microscopy. Photomicrographs were obtained with the Cool Snap Pro digital camera (Media Cybernetics, Silver Springs, MD, USA) adapted to an Olympus BX-50 light microscope (Olympus BX-50; Olympus Optical, Tokyo, Japan), which was then used to quantify the dimensions of the anatomical characteristics cited above. Thickness and area dimensions were determined using the Image Pro Plus 4.1 software (Media Cybernetics, Silver Springs, MD, USA). Five transversal sections were obtained from each leaf portion per ramet from which, in turn, one measurement for each anatomical characteristic was determined and a partial mean value was obtained for each leaf portion per ramet. For each anatomical characteristic, a final mean value was calculated using the five partial mean values obtained above for each basal and distal portion of young, mature and adult leaves.

To determine succulence, three leaf discs for each basal and distal portion, which had also been analysed in relation to strength-to-punch and anatomical characteristics, were punched with a cork borer, totalling $3.4 \times 10^{-4} \mathrm{~m}^{2}$ of area (A) per leaf portion. These discs were separated from the leaf and then gently conditioned using moistened filter papers at $7^{\circ} \mathrm{C}$ for $20 \mathrm{~h}$ (Mantovani 1999), after which the discs were superficially dried and then weighed with precision balances $(0.0001 \mathrm{~g})$ to obtain maximum fresh weight $\left(M_{f}\right)$. Finally, each disc was thoroughly dried until reaching a constant dry weight $\left(\mathrm{M}_{\mathrm{d}}\right)$ at $50^{\circ} \mathrm{C}$. One basal and one distal succulence measurement was obtained for each young, mature and old leaf studied, and a final mean value for each leaf portion was calculated. Succulence was determined as in Mantovani (1999):

Succulence $\left(\mathrm{g} \mathrm{m}^{-2}\right)=\mathrm{M}_{\mathrm{f}}-\mathrm{M}_{\mathrm{d}} / \mathrm{A}$

\section{Nutritional and chemical anti-herbivory strategies}

The same basal and distal portions of the leaves of $A$. blanchetiana used for the quantification of mechanical and morpho-physiological defences were used to assess nutritional and chemical defences by the content of leaf nitrogen, condensed tannins and phenolic compounds. Leaf nitrogen 
content (in percentage of dry biomass) was determined through the Kjeldahl method (Medina et al. 1990). For the analysis of phenolic compounds, the leaf portions were first dehydrated in an air-driven oven at $80^{\circ} \mathrm{C}$ and then ground. About $500 \mathrm{mg}$ of dried leaf was extracted with a solution of acetone-water 70:30 $(4 \times 5 \mathrm{ml})$. The resulting extracts were added to a volumetric flask $(25 \mathrm{ml})$ where the volume was adjusted. Proanthocyanidins and the Folin-Denis methods were used to determine condensed tannins and total phenolic contents, respectively (Waterman \& Mole 1994). Purified quebracho tannins were used as a standard for the quantification of condensed tannins (Hagerman \& Butler 1989). Measurements consisting of one basal and one distal measurement each of leaf nitrogen, condensed tannins and total phenolic content were obtained for each young, mature and old leaf studied, and a final mean per leaf portion was calculated.

\section{Statistical analysis}

Leaf portions (basal and distal) and positions (young, mature and old) were compared in relation to their respective herbivore-affected area and anti-herbivore strategies. Data were first tested for parametric distribution with the Kolmogorov-Smirnov test and for homocedasticity with Levene's test. Differences among parametric data were detected through one-way ANOVA and Tukey's post hoc test $(\mathrm{p}<0.05$; Zar 1996). Non-parametric data were compared with the Kruskal-Wallis and Mann-Whitney tests. Statistical analysis was performed using the Statistics 6.0 software (StatSoft Inc., Tulsa, OK, USA).

\section{Results}

\section{Quantification of consumed areas}

The degree of herbivory varied among leaf portions and positions. Only the distal portion of mature leaves and old leaves was attacked by the scraper A. pulchella. The percentage of leaf area consumed during this study varied from $1.4 \%$ to $5 \%$ for mature leaves, almost 7 times higher than the percentage found for the old ones $(\mathrm{p}<0.02)$. Young leaves of $A$. blanchetiana were not attacked by $A$. pulchella during monitoring.

\section{Mechanical and morpho-physiological anti-herbivoryleaftraits}

The basal portions of leaves, independent of the position, always presented higher maximum force and strength-topunch in comparison with the distal portion $(\mathrm{p}<0.05)$. While mean force values for the basal portion of leaves (young, mature and old basal portions) varied from 1.52 $\mathrm{kg}$ to $1.77 \mathrm{~kg}$, the mean force values to punch for the distal portion (young, mature and old distal portions) varied from $1.36 \mathrm{~kg}$ to $1.40 \mathrm{~kg}$ (Table 1). Mean strength-to-punch values followed the same pattern (ranges, $18.98-19.61 \mathrm{MN} \mathrm{m}^{-2}$ for the basal portion of leaves and $16.98-17.48 \mathrm{MN} \mathrm{m}^{-2}$ for the distal portions).

Whole leaf thickness was greater at the basal portion of mature leaves $(p<0.0001$; Table 1$)$. However, there were no differences for either of the two anatomical traits: epidermis+mechanical hypodermis thickness at adaxial surface $(\mathrm{p}=0.07)$ and the percentage of fibres occupying transversal sections of leaves $(\mathrm{p}=0.24)$.

There were also no differences between the basal and distal portions of young, mature and old leaves in relation to leaf succulence ( $p>0.226)$. Mean values of leaf succulence varied from $676 \mathrm{~g} \mathrm{~m}^{-2}$ for the distal portions of old leaves to more than $800 \mathrm{~g} \mathrm{~m}^{-2}$ for the basal portions of mature leaves (Table 1).

\section{Nutritional and chemical anti-herbivory strategies}

The mean nitrogen content varied according to distinct leaf portions $(\mathrm{p}<0.0001)$. Lower nitrogen content, approximately $0.4 \%$, was found in basal leaf portions and in the distal portion of young leaves. Higher nitrogen content was found in the distal portions of mature and old leaves: $0.6 \%$ (Table 1 ).

Table 1. Comparison among basal and distal portions of young, mature and old leaves of Aechmea blanchetiana, in terms of anti-herbivore strategies. Distinct leaves are not compared.

\begin{tabular}{lcccccc}
\hline \multirow{2}{*}{ Variable } & \multicolumn{2}{c}{ Young leaves } & \multicolumn{2}{c}{ Mature leaves } & \multicolumn{2}{c}{ Old leaves } \\
\cline { 2 - 7 } & Basal portion & Distal portion & Basal portion & Distal portion & Basal portion & Distal portion \\
\hline Maximum force-to-punch, kg & $1.57 \pm 0.29$ & $1.36 \pm 0.19^{*}$ & $1.77 \pm 0.17$ & $1.42 \pm 0.21^{*}$ & $1.52 \pm 0.22$ & $1.34 \pm 0.22^{* *}$ \\
Punch strength, $\mathrm{MN} \mathrm{m}^{-2}$ & $19.61 \pm 3.62$ & $16.98 \pm 2.37^{*}$ & $22.11 \pm 2.12$ & $16.98 \pm 2.49^{*}$ & $18.98 \pm 2.74$ & $17.48 \pm 2.99^{* *}$ \\
Whole leaf thickness, $\mu \mathrm{m}$ & $773.44 \pm 36.88$ & $728.20 \pm 61.32^{* * *}$ & $957.35 \pm 44.76$ & $707.79 \pm 37.38^{* * *}$ & $798.15 \pm 14.14$ & $669.70 \pm 44.50^{* * *}$ \\
Adaxial epidermis + hypodermis thickness, $\mu \mathrm{m}$ & $21.57 \pm 1.78$ & $14.09 \pm 3.98$ & $18.57 \pm 5.50$ & $18.81 \pm 4.03$ & $20.98 \pm 1.40$ & $23.09 \pm 0.98$ \\
Mesophyll area occupied by fibres, \% & $2.47 \pm 1.16$ & $3.53 \pm 1.72$ & $3.18 \pm 1.89$ & $2.04 \pm 1.05$ & $1.09 \pm 0.09$ & $0.81 \pm 0.44$ \\
Nitrogen content, \% & $0.42 \pm 0.02$ & $0.45 \pm 0.05$ & $0.41 \pm 0.06$ & $0.64 \pm 0.06^{*}$ & $0.44 \pm 0.02$ & $0.63 \pm 0.03^{*}$ \\
Total Phenols content, \% & $0.50 \pm 0.06$ & $0.62 \pm 0.10$ & $0.45 \pm 0.03$ & $0.67 \pm 0.09^{*}$ & $0.48 \pm 0.06$ & $0.64 \pm 0.12^{* * *}$ \\
Succulence, $\mathrm{g} \mathrm{m}^{-2}$ & $765.86 \pm 94.60$ & $757.01 \pm 76.14$ & $858.51 \pm 170.59$ & $764.39 \pm 43.17$ & $685.24 \pm 44.89$ & $676.75 \pm 62.67$ \\
\hline
\end{tabular}

Results are expressed as mean $\pm \mathrm{sd}(\mathrm{n}=5) .{ }^{*} \mathrm{p}<0.05 ;{ }^{* *} \mathrm{p}<0.01 ;{ }^{* * *} \mathrm{p}<0.001$. 
Condensed tannins were not detected in any sample (basal and apical portions of leaves). The total content of phenolic compounds differed between the basal and distal portion of the leaves $(\mathrm{p}<0.001)$. The basal portions presented mean values varying from $0.45 \%$ to $0.50 \%$, while the distal leaf portions presented higher values of $0.60 \%$ (Table 2 ).

Table 2 shows the analysis of variance comparing antiherbivore traits among all portions (basal and distal) and tank positions (young, mature and old) of A. blanchetiana leaves. The morpho-physiological characteristics of adaxial epidermis+hypodermis thickness, percentage of leaf crosssectional area occupied by fibres and succulence are not shown, as they were not statistically different $(p>0.05)$. The distal portions of mature and old leaves presented similar force and strength-to-punch values when compared with the distal portion of young leaves. However, the distal portions of mature and old leaves presented higher values of nitrogen content than the distal portions of young leaves. Whole leaf thickness was higher for the basal portion of mature leaves in relation to young and adult leaves, and total phenolic content was higher for the distal portions in comparison with the basal portions of leaves.

\section{Discussion}

Leaf loss due to herbivory of $A$. pulchella on A. blanchetiana leaves was low $(<5 \%)$, corroborating data from the literature (Frank \& Lounibos 2009). Since no attack was recorded here for either basal portions of the same leaves or any portion of young leaves, the scraper $A$. pulchella clearly presented an intraspecific feeding preference for the mid-upper portion of the mature and old leaves of A. blanchetiana. Wounds produced by this herbivore are very distinguishable and permanent. As a result, the bromeliad collection at the study site should stand as a visual report of the feeding preference of this scraper. In fact, observations at the study site confirm that the great majority of wounds are concentrated on the distal portion of mature and old leaves, but only sporadically on young leaves.

Intraspecific preferences of herbivores are commonly related to within-plant heterogeneity of mechanical, morphological, chemical and nutritional properties (Coley 1983; Coley \& Aide 1991). Also, biotic (e.g., previous damage by herbivores) and abiotic (sun and shade leaves) effects, in addition to leaf rolling and tissue development stage or age (e.g., younger versus older leaves), can affect foraging behaviour (Coley et al. 1985, Grubb et al. 2008).

Among the mechanical, morphological, chemical and nutritional anti-herbivore properties assessed here for A. blanchetiana leaves, within-plant heterogeneity was observed only for the following: mechanical properties measured by force and strength-to-punch; morphology, characterised by whole leaf thickness; and chemical characteristics indicated by nitrogen and total phenolic contents. Mechanical properties measured by punch are obviously related to leaf thickness
(Choong et al. 1992), but they can also be affected by anatomical properties, such as the density of fibres surrounding the vascular bundles (Lucas et al. 2000; Read et al. 2000) and cell wall lignification (Kursar \& Coley 1992; Balsamo et al. 2006). The basal portions of mature and old leaves of A. blanchetiana are thicker than the distal portions, but they did not differ in relation to epidermis+hypodermis thickness or extent of vascular fibres. In fact, when normalised for leaf thickness, the specific strength-to-punch values were similar for all leaf portions and ages (range, $23-26 \mathrm{GN} \mathrm{m}^{-2} \mathrm{~m}^{-1}$ ).

Considering our results, it could be suggested that the lower values based on the mechanical properties of force and strength-to-punch influenced the preference of A. pulchella for distal leaf portions. However, the younger leaves of A. blanchetiana were not attacked, even though they are obviously softer than the basal leaf portions of the other leaves. Moreover, younger leaves are usually more attacked than older leaves, as they have a higher concentration of water and nutrients in a softer structure (Coley et al. 1985). This could occasionally be the opposite when less attacked younger leaves present a higher concentration of chemical defences (e.g., tannins) than older leaves (Coley \& Aide 1991; Lokvam \& Kursar 2005). In our study, however, the total phenolic content does not seem to work as an anti-herbivore defence in young leaves, as for these compounds higher values were found on the herbivore-damaged mid-upper leaf portions. Nevertheless, no condensed tannins were found for A. blanchetiana leaves.

High tannin concentration does not necessarily deter herbivory (Mole \& Joern 1994). Many co-adapted insects, such as Anacridium melanorhodon Walker (Acrididae), eat plants containing large amounts of tannins that can even be phagostimulants (Bernays \& Woodhead 1982). These observations suggest that $A$. pulchella could have acquired resistance to the ingestion of phenols along some evolutionary pathway. Nichols-Orians (1991) suggests that leaf selection by herbivores may involve a trade-off between maximising the harvesting of nutrients while minimising the harvesting of tannins. Thus, it appears that tannins mediate the interactions between plants and specialist herbivores, mainly when there is no nutrient advantage for a feeding preference.

Initially, feeding preference for a nutrient-enriched material does not seem to be the case for bromeliad leaves. Mantovani and Iglesias (2001) point out that bromeliad leaves have a lower nutritional content in comparison with dicotyledons (Benzing 1990). Among leaf nutrients, nitrogen deserves to be highlighted since it often limits the growth of both plants and consumers (Burgess et al. 2003). While the median leaf nitrogen content for angiosperms usually ranges between approximately $1 \%$ and 5\% (Mattson 1980; Lorenzo et al. 2010), that of the same nutrient in A. blanchetiana leaves is considerably lower, varying from $0.4 \%$ to $0.6 \%$. Some studies have shown that nitrogen concentration is significantly higher in younger leaves, rendering them more palatable than adult 
Table 2. Comparisons among portions (basal and distal) and tank positions (young, mature and old) of Aechmea blanchetiana leaves, in terms of anti-herbivore strategies. The morpho-physiological characteristics of adaxial epidermis+hypodermis thickness, proportion of leaf cross-sectional area occupied by fibres and succulence are not shown, as they were no statistically significant differences among portions or tank positions for those variables.

\begin{tabular}{|c|c|c|c|c|c|c|c|}
\hline \multirow{2}{*}{ Leaf anti-herbivory strategies } & \multirow{2}{*}{$\begin{array}{l}\text { Leaf tank } \\
\text { and portion }\end{array}$} & \multicolumn{6}{|c|}{ Leaf tank and portion } \\
\hline & & YB & YD & MB & MD & OB & OD \\
\hline \multirow{6}{*}{ Maximum force-to-punch } & YB & & & & & & \\
\hline & YD & * & & & & & \\
\hline & MB & * & * & & & & \\
\hline & MD & * & & * & & & \\
\hline & OB & & * & * & & & \\
\hline & OD & * & & * & & * & \\
\hline \multirow{6}{*}{ Punch strength } & YB & & & & & & \\
\hline & YD & * & & & & & \\
\hline & MB & * & * & & & & \\
\hline & MD & * & & * & & & \\
\hline & $\mathrm{OB}$ & & * & * & & & \\
\hline & OD & * & & * & & * & \\
\hline \multirow{6}{*}{ Whole leaf thickness } & YB & & & & & & \\
\hline & YD & & & & & & \\
\hline & MB & * & * & & & & \\
\hline & MD & & & * & & & \\
\hline & OB & & & * & & & \\
\hline & OD & & & * & & & \\
\hline \multirow{6}{*}{ Nitrogen content } & YB & & & & & & \\
\hline & YD & & & & & & \\
\hline & MB & & & & & & \\
\hline & MD & * & * & * & & & \\
\hline & OB & & & & * & & \\
\hline & OD & * & * & * & & * & \\
\hline \multirow{6}{*}{ Total phenol content } & $\mathrm{YB}$ & & & & & & \\
\hline & YD & & & & & & \\
\hline & MB & & & & & & \\
\hline & MD & $* *$ & & ** & & & \\
\hline & OB & & & & $* *$ & & \\
\hline & OD & & & $* *$ & & & \\
\hline
\end{tabular}

YB - young basal; YD - young distal; MB - mature basal; MD - mature distal; OB - old basal; OD - old distal. Five replicates per segment. ${ }^{*} \mathrm{p}<0.001 ;{ }^{* *} \mathrm{p}<0.01$.

ones (Coley \& Barone 1996; Nichols-Orians \& Schultz 1990). Our results show the opposite in that the attacked distal portions of mature and old leaves of $A$. blanchetiana presented higher nitrogen content than the soft younger leaves. On the basis of these cumulative results, we can confirm that the intraspecific feeding pattern of $A$. pulchella was not guided by chemical or mechanical defences, but rather by preferences for nitrogen-enriched leaf portions.

Chemical and mechanical defences are important factors that make leaves less attractive to a herbivore (Coley et al. 1985). However, the plant-herbivore relationship can also be influenced by characteristics that increase resource quality (e.g., water and nitrogen) and then stimulate graz- ing rather than deter it. This seems to occur for A. pulchella at an intraspecific level when the scraper selects the most nitrogen-enriched leaf portions rather than the equally soft leaves of $A$. blanchetiana. We think that this intraspecific pattern could be optimal when oligotrophic food is being considered, as pointed out above for the low nutritional status of bromeliad leaves. This selective pattern was previously recorded for miners of grasses (Scheirs et al. 1997; 2001). Interestingly, grasses are similar to bromeliads at a general nutritional, chemical, mechanical and anatomical level (Almeida et al. 2009; Tomlinson 1969). Leaves of grasses have low concentrations of nutrient and active secondary compounds, as well as presenting mechanical 
defences such as a parallel array of tough vascular bundles surrounded by fibres and high levels of silica (Bernays \& Barbehenn 1987; Tscharntke \& Greiler 1995; Vieira \& Mantovani 1995). Miners of grasses also make longitudinal wounds, select tissues with a high nutrient content and avoid those with high mechanical or chemical defences. Scheirs et al. (2001) call this a "selective feeding hypothesis", stating that nutritional benefits are considered to be one of the main advantages of this selective feeding pattern. This was confirmed for grass miners, but until now, nothing has been reported for bromeliads. We conclude that the scraper $A$. pulchella presents a selective feeding pattern when attacking $A$. blanchetiana leaves, exhibiting preference for the mid-upper leaf portions with higher nitrogen content.

\section{Acknowledgements}

This work was supported by grants from the Fundação de Amparo a Pesquisa do Estado do Rio de Janeiro (FAPERJ, Rio de Janeiro Research Foundation; Grant no. 170.477/2006 to AM) and the Brazilian Conselho Nacional de Desenvolvimento Científico e Tecnológico (CNPq, National Council for Scientific and Technological Development; Grant no. 124690/2009-2 to LBF).

\section{References}

Aide, T.M. 1993. Patterns of leaf development and herbivory in a tropical understory community. Ecology 74: 455-466.

Almeida, V.R.; Costa, A.F.; Mantovani, A.; Gonçalves-Esteves, A.; Arruda, R.C.O. \& Forzza, R.C., 2009. Morphological phylogenetics of Quesnelia (Bromeliaceae, Bromelioideae). Systematic Botany 34: 660-672.

Aranwela, N; Sanson, G \& Read, J. 1999. Methods of assessing leaf-fracture properties. New Phytologist 144: 369-383.

Balsamo, R.; Vander Willigen, C; \& Farrant, J.M. 2006. Relating leaf tensile properties to drought tolerance for selected species of Eragrostis. Annals of Botany 97: 985-991.

Benzing, D.H. 1990. Vascular epiphytes. New York, Cambridge University Press.

Benzing D.H. 2000. Bromeliaceae: profile of an adaptive radiation. Cambridge, Cambridge University Press.

Bernays, E.A. \& Barbehenn, R. 1987. Nutritional ecology of grass foliagechewing insects. Pp 147-175. In: Slansk, F.; Rodriguez, J.G. (Eds.) Nutritional ecology of insects, mites, spiders and related invertebrates. New York, Wiley.

Bernays, E.A., Woodhead, S. 1982. Plant phenols utilized as nutrients by a phytophagous insect. Science 9: 201-203.

Bernays, E.A., Chapman, R.F. 1994. Host-plant selection by phytophagous insects. London, Chapman \& Hall.

Burgess, E.; Burgess J. \& Lowman, M. 1998. How quickly do bromeliads decay? Journal of the Bromeliad Society 48: 177-182.

Burgess, J.; Burgess, E.; Lowman, M. 2003. Observations of a beetle herbivore on a bromeliad in Peru. Journal of the Bromeliad Society 53: 193-240.

Choong, M.F.; Lucas, P.W.; Ong, J.S.Y.; Pereira, B.; Tan, H.T.W. \& Turner, I.M. 1992. Leaf fracture toughness and sclerophylly: their correlations and ecological implications. New Phytologist 121: 597-610.

Coley, P.D. 1983. Intraspecific variation in herbivory on two tropical trees species. Ecology 64: 426-433.
Coley, P.D. \& Aide, T.M. 1991. Comparison of herbivory and plant defenses in temperate and tropical broad-leaved forests. Pp. 25-49. In: Price, P.W.; Lewinsohn, T.M.; Fernandes, G.W. \& Benson, W.W. (Eds.). Plant-Animal Interactions: Evolutionary Ecology in Tropical and Temperate Regions. New York, Wiley \& Sons.

Coley, P.D. \& Barone, J.A. 1996. Herbivory and plant defenses in tropical forests. Annual Review of Ecology and Systematics 27: 305-335.

Coley, P.D.; Bryant, J.P. \& Chapin, F.S. III 1985. Resource availability and plant anti-herbivore defense. Science 230: 895-899.

DeVries, P.J. 1997. The butterflies of Costa Rica and their natural history. Princeton, Princeton University Press.

Dominy, N.J.; Grubb, P.J.; Jackson, R.V.; Lucas, P.W.; Metcalfe, D.J.; Svenning, J.C. \& Turner I.M. 2008. In tropical lowland rain forests monocots have tougher leaves than dicots, and include a new kind of tough leaf. Annals of Botany 101: 1363-1377.

Feeny, P. 1970. Seasonal changes in oak leaf tannins and nutrients as a cause of spring feeding by winter moth caterpillars. Ecology 51: 565-581.

Forkner, R.E.; Marquis, R.J.; Lill, J.T. 2004. Feeny revisited: condensed tannins as anti-herbivore defenses in leaf-chewing herbivore communities of Quercus. Ecological Entomology 29: 174-187.

Frank, J.H. \& Lounibos, L.P. 2009. Insects and allies associated with bromeliads: a review. Terrestrial Arthropod Reviews 1: 125-153.

Grubb, P.J.; Jackson, R.V.; Barberis, I.M.; Bee, J.N.; Coomes, D.A.; Dominy, N.J.; De La Fuente M.A.S.; Lucas, P.W.; Metcalfe, D.J.; Svenning, J.C. \& Turner, I.M. 2008. Monocot leaves are eaten less than dicot leaves in tropical lowland rain forests: roles for toughness and leaf presentation. Annals of Botany 101: 1379-1389.

Hagerman, A.E. \& Butler, L.G. 1989. Choosing appropriate methods and standard for assaying tannin. Journal of Chemical Ecology 15: 1795-1810.

Harbone, J.B. 1982. Introduction to ecological biochemistry. New York, Academic Press.

King, B.L. 1988. Design and evaluation of a simple penetrometer for measuring leaf toughness in studies of insect herbivory. Virginia Journal of Science 39: 405-408.

Kursar, T.A. \& Coley, P.D. 1992. Delayed development of the photosynthetic apparatus in tropical forest species. Functional Ecology 6: 411-422.

Lokvam, J. \& Kursar, T.A. 2005. Divergence in structure and activity of phenolic defenses in young leaves of two co-occurring Inga species. Journal of Chemical Ecology 31: 2563-80.

Lorenzo, N.; Mantuano, D. \& Mantovani, A. 2010. Comparative leaf ecophysiology and anatomy of seedlings, young and adult individuals of the epiphytic aroid Anthurium scandens (Aubl.) Engl.. Environmental and Experimental Botany 68: 314-322.

Lowman, M.D. \& Box J.D. 1983. Variation in leaf toughness and phenolic content among five species of Australian rain forest trees. Australian Journal of Ecology 8: 17-25.

Lowman, M.D.; Wittman, P.K. \& Murray, D. 1996. Herbivory in a bromeliad of the Peruvian rain forest canopy. Journal of the Bromeliad Society 46: 52-55.

Lucas, P.W.; Turner, I.M.; Dominy, N.J. \& Yamashita, N. 2000. Mechanical defences to herbivory. Annals of Botany 86: 913-920.

Mantovani, A. 1999. Leaf morphophysiology and distribution of epiphytic aroids along a vertical gradient in a Brazilian Rain Forest. Selbyana 20: 241-249.

Mantovani, A. \& Iglesias R.R. 2001. Bromélias terrestres na restinga de Barra de Maricá, RJ: influência sobre o microclima, o solo, e a estocagem de nutrientes em ambientes de borda de moitas. Leandra 16: 17-37.

Mantovani, A. \& Pereira T.E. 2005. Comparative anatomy of leaf and spathe of nine species of Anthurium (section Urospadix; subsection Flavescentiviridia) (Araceae) and their diagnostic potential for taxonomy. Rodriguésia 56: 145-160.

Mantovani, A.; Magalhães, N.; Teixeira, M.; Leitão, G.; Staines, C.L. \& Rezende, B. 2005. First report on host plants and feeding habits of the leaf beetle Acentroptera pulchella Guérin-Méneville (Chrysomelidae, Hispinae). Pp. 153-157. In: Konstantinov, A.; Tishechkin, A. \& Penev, L. (Eds.) Contributions to Systematics and Biology of Beetles. Moscou, Pensoft Publishers. 
Mattson, W.J. 1980. Herbivory in relation to plant nitrogen content. Annual Review of Ecology and Systematics 11: 119-161.

Medina, E.; Garcia, V. \& Cuevas, E. 1990. Sclerophylly and oligotrophic environments: relationships between leaf structure, mineral nutrient content, and drought resistance in tropical rain forest of the upper Rio Negro region. Biotropica 22: 51-64.

Mole, S. \& Joern, A. 1994. Feeding behavior of graminivorous grasshoppers in response to host-plant extracts, alkaloids, and tannins. Journal of Chemical Ecology 20: 3097-3109.

Nichols-Orians, C.M. 1991. The effects of light on foliar chemistry, growth and susceptibility of seedlings of a canopy tree to an attine ant. Oecologia 86: $552-560$.

Nichols-Orians, C.M. \& Schultz, J.C. 1990. Interactions among leaf toughness, chemistry, and harvesting by attine ants. Ecological Entomology 15: 311-320.

Read, J. \& Sanson, G.D. 2003. Characterizing sclerophylly: the mechanical properties of a diverse range of leaf types. New Phytologist 160: 81-99.

Read, J.; Edwards, C.; Sanson, G.D. \& Aranwela N. 2000. Relationships between sclerophylly, leaf biomechanical properties and leaf anatomy in some Australian heath and forest species. Plant Biosystems 134: 261-277.

Sagers, C.L. \& Coley P.D. 1995. Benefits and costs of defense in a neotropical shrub. Ecology 76: 1835-1843.

Scheirs, J.; Vandevyvere, I. \& De Bruyn, L. 1997. Infuence of monocotyl leaf anatomy on the feeding pattern of a grass-mining agromyzid (Diptera). Annals of the Entomological Society of America 90: 646-654.
Scheirs, J.; De Bruyn, L. \& Verhagen, R. 2001. Nutritional benefits of the leaf-mining behaviour of two grass miners: a test of the selective feeding hypothesis. Ecological Entomology 26: 509-516.

Schmidt, G. \& Zotz, G. 2000. Herbivory in the epiphyte, Vriesea sanguinolenta Cogn. and Marchal (Bromeliaceae). Journal of Tropical Ecology 16: 829-839.

Scriber, J.M. 1977. Limiting effects of low leaf-water content on the nitrogen utilization, energy budget, and larval growth of Hyalophora cecropia (Lepdoptera: Saturniidae). Oecologia 28: 269-287.

Tomlinson, P.B. 1969. Comelinales - Zingiberales. Pp 193-294. In: Metcalfe CR (Ed.). Anatomy of the monocotyledons III. Oxford, Claredon Press.

Tscharntke, T. \& Greiler, H.J. 1995. Insect communities, grasses, and grasslands. Annual Review of Entomology 40: 535-558.

Vieira, R.C. \& Mantovani A.1995. Anatomia foliar de Deschampsia antarctica Desv. (Gramineae). Revista Brasileira de Botanica 18: 207-220.

Waterman, P.G. \& Mole, S. 1994. Analysis of phenolic plant metabolites. Pp 36-43. In: Lawton J.H, Likens GE (Eds.). Methods in Ecology. Oxford, Blackwell Scientific Publication.

Wheeler, G.S. \& Center, T.D. 1996. The influence of Hydrilla leaf quality on larval growth and development of the biological control agent Hydrellia pakistanae (Diptera: Ephydridae). Biological Control 7: 1-9.

Wheeler, G.S. \& Center, T.D. 2001. Impact of the biological control agent Hydrella pakistanae (Diptera: Ephydae) on the submersed aquatic weed Hydrilla verticillata (Hydrocharitaceae). Biological Control 21: 168-181.

Zar, J.H. 1996. Biostatistical Analysis. 3 ed. New Jersey, Prentice Hall. 